\title{
Recent advances in diesel autothermal reformer
}

\section{design}

\author{
Joachim Pasel,* Remzi Can Samsun, Jan Meißner, Andreas Tschauder and Ralf Peters \\ Forschungszentrum Jülich GmbH, Institute of Energy and Climate Research, IEK-14: \\ Electrochemical Process Engineering, 52425 Jülich, Germany
}

\begin{abstract}
Autothermal reforming; diesel; kerosene; reactor development; pulse valve for fuel injection; fuel cell systems

* Corresponding author: tel: +49 2461 615140; fax: +49 2461 616695; e-mail: j.pasel@ffjuelich.de
\end{abstract}

\begin{abstract}
The autothermal reforming of diesel fuel is a catalytic process that runs at temperatures of $700{ }^{\circ} \mathrm{C}$ to $900{ }^{\circ} \mathrm{C}$. Long-chain hydrocarbon molecules react with steam and $\mathrm{O}_{2}$, yielding a product gas that mainly consists of $\mathrm{CO}, \mathrm{CO}_{2}, \mathrm{CH}_{4}$ and $\mathrm{H}_{2} . \mathrm{H}_{2}$ is essential for the operation of fuel cell systems. The Forschungszentrum Jülich has been engaged in the cooperative development of technical apparatus for this reaction to be applied in fuel cell systems over the past 15 years, together with many other research groups worldwide, and this paper deals with reactor ATR 14, which is considered the preliminary end-product of Jülich's research and development in this field. This paper briefly summarizes Jülich's earlier reactor generations and then describes the most recent improvements embodied in the ATR 14. Additionally, the experimental evaluation of the ATR 14 is presented, which demonstrates that it can be operated over a broad load range and with almost complete carbon conversion.
\end{abstract}

\section{Introduction}

The continuous increase in greenhouse gas emissions in the transport sector of the European Union over the past 25 years is harmful to the climate in the long term and underlines the necessity for new, environmentally-friendly technologies in the transport sector [1]. There are many options in this respect such as, for instance, electric vehicles that utilize batteries charged by renewable energy, power-to-fuel processes that produce carbon-neutral feedstocks 
for conventional internal combustion engines, as well as vehicles that run on natural gas or on the basis of fuel cell systems. Fuel cell systems operated on renewable $\mathrm{H}_{2}$ can be applied to vehicle propulsion itself, whereas fuel cell systems using reforming processes for $\mathrm{H}_{2}$ generation from liquid carbonaceous energy carriers are suitable for auxiliary power units (APUs) for on-board power supply in aircraft or trucks (i.e., for air conditioning, heating, cabin systems, etc.). Samsun et al. [2] explain that fuel cell-based APUs with diesel reforming can achieve an efficiency of $40 \%$, which is the efficiency target of the U.S. Department of Energy $[3,4]$. One of the most important and complex components of such an APU is the reforming unit for generating $\mathrm{H}_{2}$ from liquid carbonaceous feedstocks, for which autothermal reforming (ATR), heated steam reforming (HSR) and partial oxidation (POX) are the most common processes. At Jülich, ATR is preferred for reactor development, as it was shown experimentally that it is the most dynamic, simple and robust design. During ATR, the liquid hydrocarbon feedstock reacts with steam and $\mathrm{O}_{2}$, generating a gas mixture (reformate) that ideally consists of only $\mathrm{H}_{2}, \mathrm{CO}, \mathrm{CO}_{2}$ and traces of $\mathrm{CH}_{4}$. A large number of liquid feedstocks for ATR have been investigated in the literature. These include jet fuels, diesel fuels (fossil and synthetic) and different substitute materials that are similar to jet and diesel fuels but that avoid aromatic substances and sulfur [5-21]. In addition, biogenic fuels for ATR have been attracting ever more attention in recent years [22-29]. When running ATR with biogenic fuels, it was found that coke formation at the catalytically-active sites was a major concern. This can be suppressed by increasing the partial pressure of $\mathrm{O}_{2}$ in the ATR educt mixture. As with almost all chemical processes, the choice of a suitable ATR catalyst is decisive for the complete conversion of carbonaceous feedstocks and promising long-term stability. In the relevant literature, $\mathrm{Rh}, \mathrm{Pt}, \mathrm{Ru}, \mathrm{Ir}$ and $\mathrm{Ni}$ are deposited on different washcoats such as $\mathrm{Al}_{2} \mathrm{O}_{3}$, $\mathrm{SiO}_{2}, \mathrm{CeO}_{2}, \mathrm{ZrO}_{2}$ or perovskites, and have been found to best fulfill the requirements of high activity and stability [30-47]. High activity and stability, however, are threatened by the above-mentioned coke deposits and, additionally, by adsorbing sulfur- and phosphorouscontaining components, which might block the catalytically-active sites on the catalyst surface being no longer accessible for the reactants. There are numerous papers in the literature regarding experimental investigations in this respect [48-60]. Although the formation of coke deposits on the catalyst surface is known to be one of the most important reasons for catalyst deactivation, only a few papers deal with a priori technical approaches to suppress them [23, 61-64]. They describe technologies for diesel fuel injection into the ATR reactor that aim to generate a spray of very fine hydrocarbon drops that can be more easily evaporated by the enthalpy flow in the evaporation section of the ATR reactor and then homogeneously blend with steam and $\mathrm{O}_{2}$. It is explained in these papers that the formation of especially ethylene as a precursor of coke formation on the catalyst surface can thereby be significantly suppressed. Han et al. developed an ATR concept for submarine application where there is only little $\mathrm{O}_{2}$ available. They simply substituted the above-mentioned reactants of steam and $\mathrm{O}_{2}$ by liquid $\mathrm{H}_{2} \mathrm{O}_{2}$. However, their system turned out to be somewhat more 
complicated, as they had to integrate an additional component into the system layout for the decomposition of $\mathrm{H}_{2} \mathrm{O}_{2}$ prior to the reforming reactions [65-68].

This paper describes the most recent improvements to Jülich's ATR reactor generation ATR 14 with respect to its design, its commercially-relevant production techniques and its experimental evaluation. Crucial process parameters to be investigated at the steady-state operation of the reformer are the reformer load and the mass fraction of cold water to the nozzle on the top side of the ATR 14. Corresponding experimental results (temperature trends at different positions inside ATR 14, concentrations of main and by-products in the gas phase and condensed excess water, respectively) are also given. In addition, a special pulse valve was applied in order to be able to perform experiments over a broad load range.

\section{Experimental}

At maximum load, ATR 14 can generate a molar flow of $\mathrm{H}_{2}$ with a thermal power of $28 \mathrm{~kW}$. To lower the activation energy of the reactions occurring during autothermal reforming, a proprietary $\mathrm{RhPt}$ catalyst on an $\mathrm{Al}_{2} \mathrm{O}_{3}-\mathrm{CeO}_{2}$ support from Umicore $\mathrm{AG} \& \mathrm{Co} . \mathrm{KG}$ (protonics A Type) was applied. Catalyst and support were deposited on a cordierite monolith with a mesh size of $600 \mathrm{cpsi}$. The gas hourly space velocity (GHSV) is approximately $30,000 \mathrm{~h}^{-1}$ at an $\mathrm{O}_{2} / \mathrm{C}$ molar ratio of 0.47 and an $\mathrm{H}_{2} \mathrm{O} / \mathrm{C}$ molar ratio of 1.9 at $100 \%$ load of ATR 14 . Ultimate diesel fuel, a commercially-available sulfur-free premium diesel fuel containing approximately $15 \mathrm{wt} \%$ aromatics with a final boiling point of $360{ }^{\circ} \mathrm{C}$, was used for all of the experiments. It is made from crude oil in a refinery with a hydrocracking step lowering the sulfur mass fraction to less than $1 \mathrm{ppm}$. Analyses by means of gas chromatography have shown that the aliphatic mass fraction mainly consists of linear $\mathrm{C}_{15}-\mathrm{C}_{24}$ alkanes and their branched isomers. The aromatic mass fraction of Ultimate diesel fuel reveals alkylated (chains with 3 and 4 carbon atoms, respectively) benzene and naphthalene molecules. The molecular formula was found to be $\mathrm{C}_{19} \mathrm{H}_{38}$. The general technical set-up and analytical equipment to qualitatively and quantitatively analyze the reformate leaving ATR 14 are also comprehensively outlined in Pasel et al. [69].

In addition, Meißner et al. [70] recently developed an improved methodology for the analysis of very low amounts (in the sub-ppm range) of residual hydrocarbons in the product gas phase of autothermal reforming. This is based on a coupling of gas-chromatography and mass spectrometry. This methodology was applied to most of the experiments in this paper. All of the experimental details in this respect can be found in Meißner et al. [70].

The pulse valve for the load change experiments was supplied by the German company, GSR Ventiltechnik GmbH \& Co. In the captions of figures 2-4 and 6-8, the temperatures of the air to the annular air injector and of the steam from the catalytic burner are abbreviated with TAI and $\mathrm{TCB}$, respectively. 


\section{Reactor development}

In earlier publications by the fuel processing group at IEK-14 [71-74], the fundamental layout of Jülich's reactors for autothermal reforming and the progress achieved over the years during the continual development based on this fundamental design are described in detail. The ATR 14, whose specific design is shown in Figure 1, is the preliminary outcome of this progressive development. Briefly, as with all previous ATR generations from Jülich, the chemical reactions are supported by a bimetallic Rhodium/Platinum catalyst deposited on an $\mathrm{Al}_{2} \mathrm{O}_{3} / \mathrm{CeO}_{2}$ washcoat, which in turn is applied to a monolithic cordierite substrate. A nozzle at the bottom of ATR 14 injects cold diesel fuel into the fuel evaporation chamber, where the diesel fuel is heated-up, evaporated and then blended with air and superheated steam, which are the other two reactants of autothermal reforming. Superheated steam at temperatures between $200{ }^{\circ} \mathrm{C}$ and $250{ }^{\circ} \mathrm{C}$ comes from the catalytic burner of the fuel processing system and is additionally heated by the enthalpy flow (waste heat) of the autothermal reforming process itself to $400-480{ }^{\circ} \mathrm{C}$ via the internal superheater, which is executed as concentric shells with electric heating wire for start-up. This is one mass fraction of water fed to the ATR 14. The other mass fraction is cold $\left(20^{\circ} \mathrm{C}\right)$ and injected, via a second nozzle, at the top of ATR 14 into the steam generation chamber. The percentage share of this cold water stream to the second nozzle is an important reaction parameter to be investigated in this paper. Air is injected into the reactor via the superheater and, additionally, through the annular air injector of the autothermal reforming reactor [75]. As mentioned above, more information regarding the general functioning and layout of Jülich's autothermal reformer generations are given by Pasel et al. [71-73].

However, there are two features of the ATR 14 that constitute its novelty and make it unique in comparison to Jülich's earlier autothermal reformer generations.

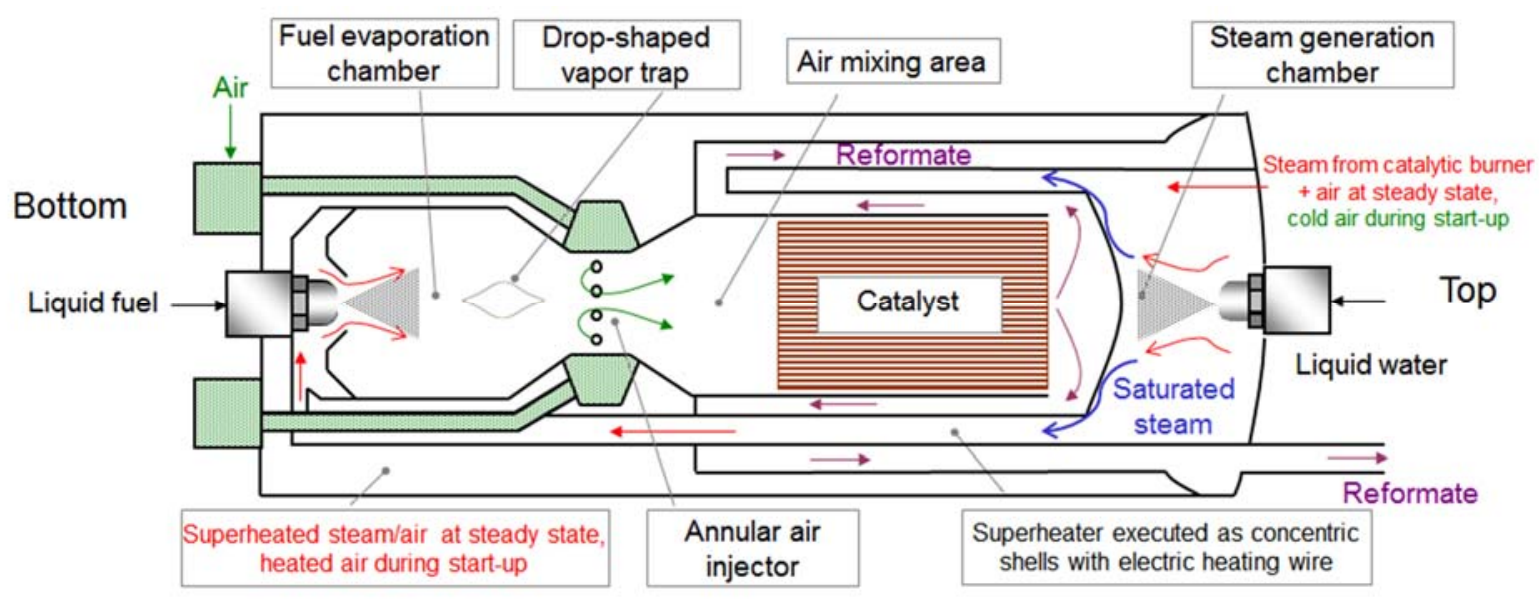

Figure 1 Design of Jülich's autothermal reformer, ATR 14

- Many parts of ATR 14 were commercially produced by means of sheet metal forming. Thus far, in autothermal reformer generations, milling was applied to produce all single parts. This change in the production technology makes the assembly of ATR 14 
much more cost- and time-efficient and constitutes a major step towards the mass production of ATR 14.

- Additionally, in the center of the fuel evaporation chamber, a drop-shaped vapor trap was incorporated into the design of ATR 14 (cf. Figure 1). This device has the function of protecting the $\mathrm{Rh} / \mathrm{Pt}$ catalyst from being hit by fuel drops originating from the nozzle for fuel injection, shown leftmost in Figure 1. Whenever a fuel drop hits this vapor trap, it directly evaporates on the trap's hot surface, which has temperatures of $300-500{ }^{\circ} \mathrm{C}$ at steady-state operation depending on the reaction conditions, and homogeneously blends with the stream of the other reactants (steam and air) due to the high turbulence of the flow. This process is particularly important when fuel injection into the fuel evaporation chamber of ATR 14 is performed in pulse mode via a special pulse valve. As is mentioned above, applying such a valve is of special interest to widen the load range of ATR 14 to values between, e.g., $20 \%$ to $100 \%$, referring to the design point of ATR 14. During each opening of the valve, the velocity of the fuel to be pulsed is equal to zero at the outlet of the nozzle, i.e., the liquid fuel does not possess any kinetic energy during the opening of the valve. According to the paper of Lee et al. [76], as a consequence of lacking kinetic energy, there does not exist any air core or fuel film on the inner surface of the nozzle's bore. Both are necessary to form a fuel lamella outside the nozzle, which finally decomposes into very fine fuel droplets. As long as this lamella is not yet formed, comparatively large fuel drops are produced at this point. This was experimentally-demonstrated in the paper by Peters et al. [77]. Thus, without the drop-shaped vapor trap, these large drops would then move in the axial direction of the reformer towards the monolith and hit the catalyst particles, on whose surface they would possibly decompose, forming carbonaceous deposits, which in turn are known to deteriorate the catalytic activity for the autothermal reforming reaction.

\section{Results and discussion}

On the left-hand side, Figure 2 displays the mass streams of water and diesel fuel and the volumetric flow of air during a load change experiment using the above-mentioned pulse valve for diesel fuel injection. According to the reformer design explained above, the mass stream of water consisted of those to the superheater and nozzle, respectively, and the flow of air was made up of the single flows to the annular air injector and superheater, respectively. For reasons of simplicity, only the total amounts are displayed in this figure. It can be seen that by operating the pulse valve, the reformer load could be varied between $20 \%$ and $100 \%$. Both the total mass streams and volumetric flow of air were stable at each load point. On the right-hand side, the respective temperatures at the outlet of the monolith, in the fuel evaporation chamber and the air mixing area are shown. In addition, the dry $\mathrm{H}_{2}$ concentrations across the entire load change experiment are depicted. At all load points, the displayed 
temperatures inside the ATR 14 were fairly stable, indicating that the ATR 14 can be smoothly run using the pulse valve. This finding is underlined by the trend of the $\mathrm{H}_{2}$ concentrations. $\mathrm{H}_{2}$ concentrations were constant in the range between $37 \mathrm{vol} \%$ and $38 \mathrm{vol} \%$.
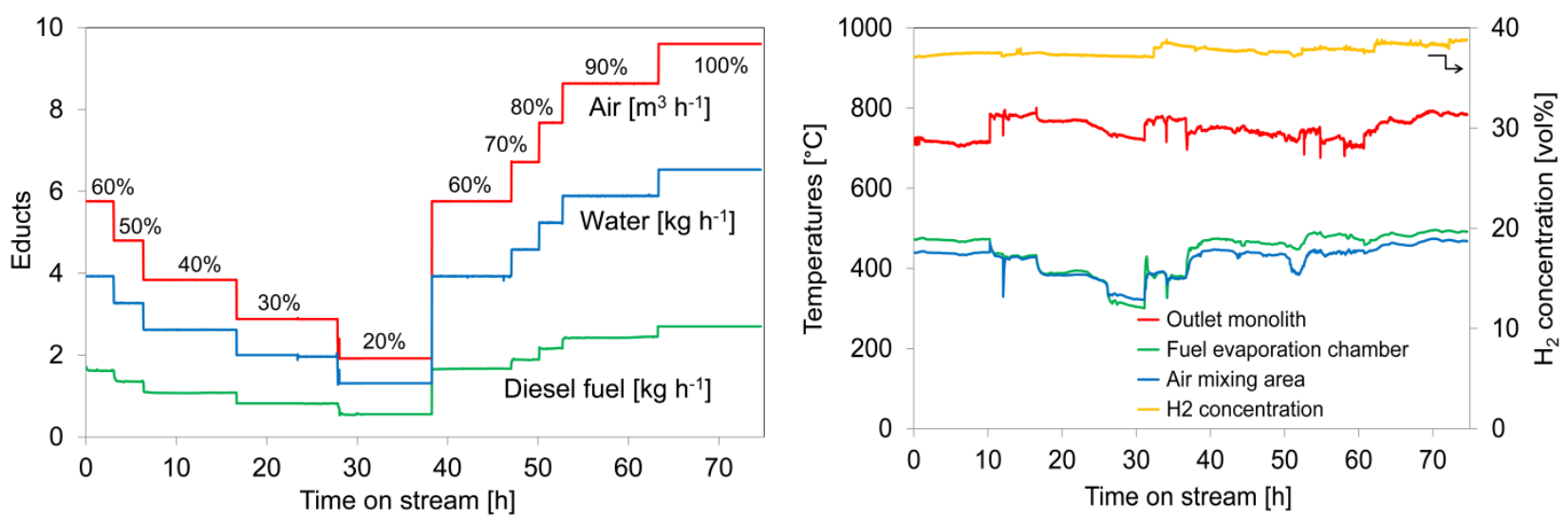

Figure 2 Left: Mass streams and volumetric flow of the educts during a load change experiment using the pulse valve for diesel fuel injection, $\mathrm{n}\left(\mathrm{O}_{2}\right) / \mathrm{n}(\mathrm{C})=0.47$, $\mathrm{n}\left(\mathrm{H}_{2} \mathrm{O}\right) / \mathrm{n}(\mathrm{C})=1.9$, TAI $=380^{\circ} \mathrm{C}, \mathrm{TCB}=230^{\circ} \mathrm{C}$, Ultimate diesel fuel, mass fraction of cold water to the nozzle: $40 \%$

Right: Temperatures inside the ATR and dry $\mathrm{H}_{2}$ concentrations in the reformate during a load change experiment using the pulse valve for diesel fuel injection, $\mathrm{n}\left(\mathrm{O}_{2}\right) / \mathrm{n}(\mathrm{C})=0.47, \quad \mathrm{n}\left(\mathrm{H}_{2} \mathrm{O}\right) / \mathrm{n}(\mathrm{C})=1.9, \quad \mathrm{TAI}=380^{\circ} \mathrm{C}$ $\mathrm{TCB}=230^{\circ} \mathrm{C}$, Ultimate diesel fuel, mass fraction of cold water to the nozzle: $40 \%$

The following figures and explanations deal with experiments with ATR 14 at steady-state operation for which the pulse valve was not applied. Therefore, the reformer load range was limited to values of between $50 \%$ and $100 \%$. Figure 3 shows the temperatures at three different characteristic positions inside the autothermal reformer ATR 14 as a function of the reformer load and mass fraction of cold water to the nozzle. During these experiments, the $\mathrm{O}_{2} / \mathrm{C}$ molar ratio was set to 0.47 , while the $\mathrm{H}_{2} \mathrm{O} / \mathrm{C}$ molar ratio had a value of 1.9 . Air was fed at $380{ }^{\circ} \mathrm{C}$ into the air mixing area through the annular injector, while steam (together with $30 \%$ of the total flow of air as carrier gas) from the catalytic burner of the fuel processing unit had a temperature of $230{ }^{\circ} \mathrm{C}$. Ultimate diesel fuel was used. In the left-hand part of Figure 3, when the mass fraction of cold water to the nozzle amounted to $30 \%$, temperatures at the outlet of the catalytically-coated monolith were close to $700{ }^{\circ} \mathrm{C}$ and almost independent of the reformer load. At reformer loads of between 50\% and $90 \%$, the temperature level in the air mixing area and fuel evaporation chamber showed a slightly decreasing trend from $580{ }^{\circ} \mathrm{C}$ to $560{ }^{\circ} \mathrm{C}$ (air mixing area) and from $450{ }^{\circ} \mathrm{C}$ to $410{ }^{\circ} \mathrm{C}$ (fuel evaporation chamber), respectively. This temperature level is much higher than can be expected based on the temperature level of the educts $\left(380{ }^{\circ} \mathrm{C}\right.$ for air and $230{ }^{\circ} \mathrm{C}$ for steam/air) and can only be explained by a homogeneous pre-reaction of some light hydrocarbons contained in Ultimate diesel fuel and $\mathrm{O}_{2}$ in the fuel evaporation chamber, and especially in the air mixing area. As the reformer 
load increased, the hydrodynamic residence time of the reactants to establish this pre-reaction decreased and thus the pre-reaction slowly began to extinguish. When changing from $90 \%$ load to $100 \%$ load, the temperature decrease at these positions was most pronounced as the residence time and thus the reaction time available for the hydrocarbon and oxygen molecules to react further decreased.
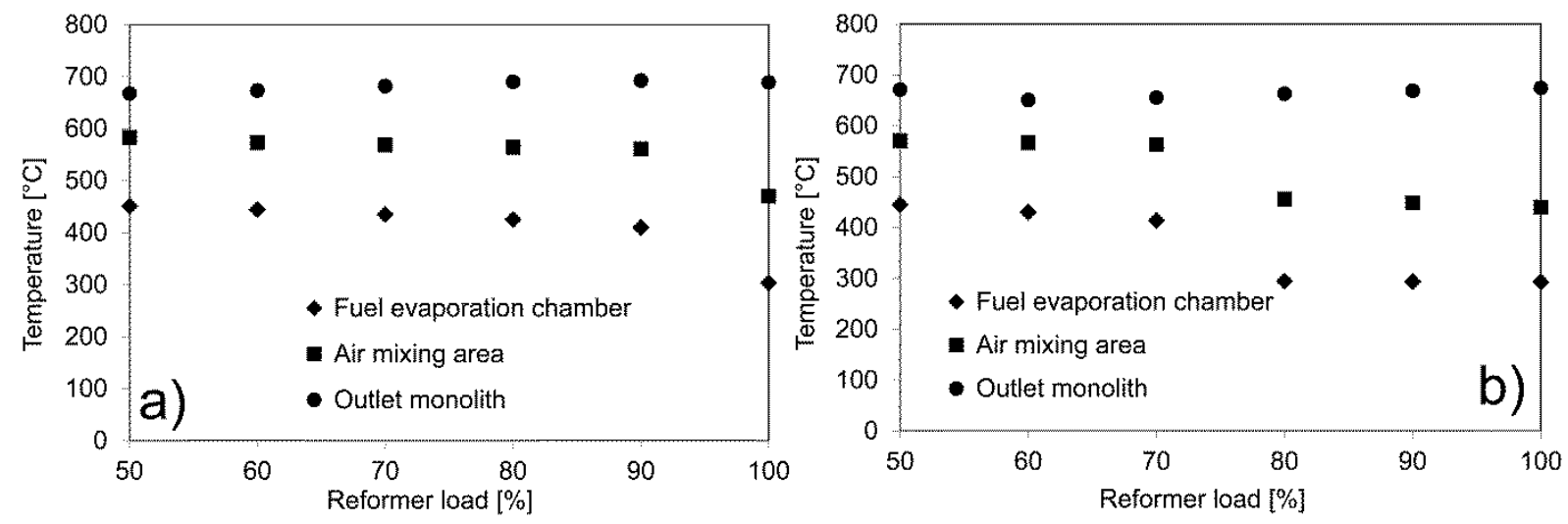

Figure 3 Temperatures inside the autothermal reformer ATR 14 as a function of the reformer load, $\mathrm{n}\left(\mathrm{O}_{2}\right) / \mathrm{n}(\mathrm{C})=0.47, \quad \mathrm{n}\left(\mathrm{H}_{2} \mathrm{O}\right) / \mathrm{n}(\mathrm{C})=1.9, \quad \mathrm{TAI}=380{ }^{\circ} \mathrm{C}$, $\mathrm{TCB}=230^{\circ} \mathrm{C}$, Fuel: Ultimate diesel, mass fraction of cold water to the nozzle a) $=30 \%$; $)=40 \%$

On the right-hand side, very similar trends can be found, when $40 \%$ of the mass stream of water were fed, cold, into the steam generation chamber. In general, due to the lower enthalpy flow into ATR 14 under these reaction conditions, all temperature levels were slightly lower in comparison to the figure on the left and the distinct drop in temperatures in the air mixing area and fuel evaporation chamber already occurred at the step from $70 \%$ to $80 \%$ reformer load. However, both figures show that under all reaction conditions, temperatures in the air mixing area and fuel evaporation chamber were high enough to guarantee complete evaporation of Ultimate diesel fuel as a decisive precondition for autothermal reforming with a high carbon conversion of close to $100 \%$. At mass fractions of cold water to the nozzle of $50 \%$ and $60 \%$ (not shown in Figure 3), only at low reformer loads of $50 \%$ and $60 \%$ the respective temperature levels were high enough to ensure complete Ultimate diesel fuel evaporation. At higher reformer loads, temperatures in the air mixing area and the fuel evaporation chamber sharply dropped (the pre-reaction almost extinguished) due to the lower enthalpy flow and shorter residence times. Thus, it can be concluded that ATR 14 can be properly operated at reformer loads of between $50 \%$ and $100 \%$, when the mass stream of cold water does not exceed $40 \%$.

In addition to Figure 3, Figure 4 displays the dry concentrations of the main products of ATR, i.e., $\mathrm{H}_{2}, \mathrm{CO}, \mathrm{CO}_{2}$ and $\mathrm{CH}_{4}$, as a function of the reformer load and mass fraction of cold water to the nozzle detected during the same series of experiments shown in Figure 3. During the autothermal reforming of liquid hydrocarbon feedstocks, $\mathrm{H}_{2}, \mathrm{CO}, \mathrm{CO}_{2}$ and $\mathrm{CH}_{4}$ are formed in 
accordance with the reactions (1) to (4) outlined below. In both figures, when the mass fractions of cold water to the nozzle amounted to $30 \%$ and $40 \%$, respectively, $\mathrm{H}_{2}$ concentrations were very stable and almost independent of the reformer load, showing values between approximately $37 \mathrm{vol} \%$ and $39 \mathrm{vol} \%$. The same is true for the concentrations of CO and $\mathrm{CO}_{2}$. While the concentrations of $\mathrm{CO}_{2}$ amounted to values of between approximately $12.0 \mathrm{vol} \%$ and $12.5 \mathrm{vol} \%$, those of $\mathrm{CO}$ were between roughly $10 \mathrm{vol} \%$ and $11 \mathrm{vol} \%$. Describing the temperatures at the outlet of the monolith in Figure 3, it is stated that due to the lower enthalpy flow in the case of the mass fraction of cold water to the nozzle of $40 \%$ in comparison to $30 \%$, the temperatures at the outlet of the monolith were slightly lower in comparison to the $30 \%$ case. This temperature difference can be retrieved in the $\mathrm{CH}_{4}$ concentrations in the reformate. While the $\mathrm{CH}_{4}$ concentrations varied between approximately 800 ppmv and 1100 ppmv, when $30 \%$ of the water mass stream was coldly injected into the steam generation chamber of ATR 14, they were significantly higher, at between 1500 ppmv and $1700 \mathrm{ppmv}$ in the $40 \%$ case. As the methanation reaction in equation (4) is exothermic, comparatively lower temperatures shift the equilibrium of this reaction to the right-hand side, thus producing comparatively higher amounts of $\mathrm{CH}_{4}$. It can be concluded from the results in this figure that ATR 14 runs in a stable manner at reformer loads of between $50 \%$ and $100 \%$ when the mass streams of cold water to the nozzle were set to values of $30 \%$ and $40 \%$, respectively.

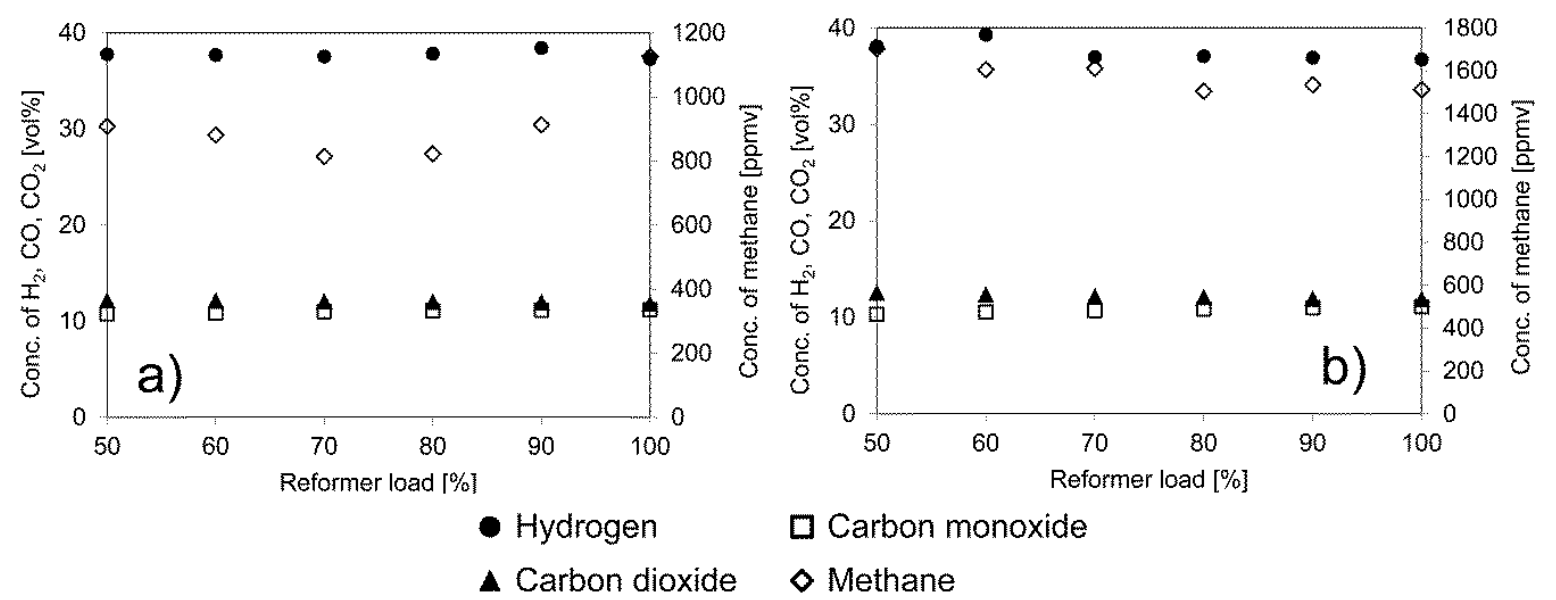

Figure 4 Dry concentrations of the main products of ATR 14 as a function of the reformer load, $\mathrm{n}\left(\mathrm{O}_{2}\right) / \mathrm{n}(\mathrm{C})=0.47, \quad \mathrm{n}\left(\mathrm{H}_{2} \mathrm{O}\right) / \mathrm{n}(\mathrm{C})=1.9, \quad \mathrm{TAI}=380{ }^{\circ} \mathrm{C}$, $\mathrm{TCB}=230^{\circ} \mathrm{C}$, Fuel: Ultimate diesel, mass fraction of cold water to the nozzle a) $=30 \%$; $)=40 \%$ 


$$
\begin{array}{llll}
\mathrm{C}_{\mathrm{n}} \mathrm{H}_{\mathrm{m}}+\mathrm{n} \mathrm{H}_{2} \mathrm{O} & \mathrm{nCO}+(\mathrm{m} / 2+\mathrm{n}) \mathrm{H}_{2} & \text { endothermic } \\
\mathrm{C}_{\mathrm{n}} \mathrm{H}_{\mathrm{m}}+\mathrm{n} / 2 \mathrm{O}_{2} & \longleftrightarrow & \mathrm{n} \mathrm{CO}+\mathrm{m} / 2 \mathrm{H}_{2} & \text { exothermic } \\
\mathrm{CO}+\mathrm{H}_{2} \mathrm{O} & \longleftrightarrow & \mathrm{CO}_{2}+\mathrm{H}_{2} & \text { exothermic } \\
\mathrm{CO}+3 \mathrm{H}_{2} & \longleftrightarrow & \mathrm{CH}_{4}+\mathrm{H}_{2} \mathrm{O}
\end{array}
$$

The following figures deal with the experimental determination of carbon conversion for each experiment of this study. Pasel et al. [78] note that in their paper about a long-term autothermal reforming experiment for 10,000 hours on stream that carbon conversion is complete if no products other than $\mathrm{H}_{2}, \mathrm{CO}, \mathrm{CO}_{2}$ and $\mathrm{CH}_{4}$ are formed. The undesiredcarboncontaining by-products of autothermal reforming can be experimentally measured (i) in the dry reformate; (ii) in the mass stream of residual water being condensed at the outlet of ATR 14; and (iii) as a liquid oily residue floating on the residual condensed water stream leaving ATR 14. As the latter was not observed in any of the experiments, carbon conversion can be calculated according to equation (5):

$$
X_{C}=1-\frac{\sum_{q=1}^{12} q \cdot y_{C_{q} H_{p}} \cdot \dot{n}_{D r y}+\frac{T O C}{M_{C}} \cdot \frac{\dot{m}_{H_{2} O}^{a q}}{\rho_{H_{2} O}^{a q}}}{n \cdot \frac{\dot{m}_{C_{n} H_{m}}}{M_{C_{n} H_{m}}}}
$$

In this equation, $y_{C_{q} H_{p}}$ are the molar fractions of the different undesired hydrocarbons in the reformate, $\dot{n}_{D r y}$ is the dry molar reformate outlet flow, TOC is the measured amount of total organic carbon in the residual condensed water stream, $\dot{m}_{\mathrm{H}_{2} \mathrm{O}}^{a q}$ is the mass stream of condensed water, $\dot{m}_{C_{n} H_{m}}$ is the mass inlet stream of Ultimate diesel fuel, $\rho_{H_{2} O}^{a q}$ is the density of water and $M_{C_{n} H_{m}}$ and $M_{C}$ are the molar masses of Ultimate diesel fuel and carbon, respectively.

The advanced analysis of the composition of the dry reformate of ATR 14 by means of gaschromatography and mass spectrometry corresponding to the method of Meißner et al. [70] showed that apart from the above shown main products of $\mathrm{H}_{2}, \mathrm{CO}, \mathrm{CO}_{2}$ and methane, as well ethene, ethane, propene, propane, iso-butene, 1-butene, 1,3-butadiene, n-butane, 2-butene, 1pentene, 1-hexene, benzene, cyclohexane and toluene, which are formed in undesired side reactions and at different amounts depending on the reaction conditions. These components jointly made up the molar fraction of unconverted carbon $y_{C}$ in the dry reformate being calculated according to equation (6):

$$
y_{C}=\sum_{q=1}^{12} q \cdot y_{C_{q} H_{p}}
$$


Figure 5 shows an exemplary gas-chromatogram from this paper's series of experiments with the signals of the above-mentioned substances, including their retention times. It can be seen that the retention times became longer with increasing number of carbon atoms in the substance. In particular, the substances with four carbon atoms (butane group) had very similar retention times at around $20 \mathrm{~min}$. However, by carefully setting the bounds of integration for each single peak, an exact quantitative analysis was possible.

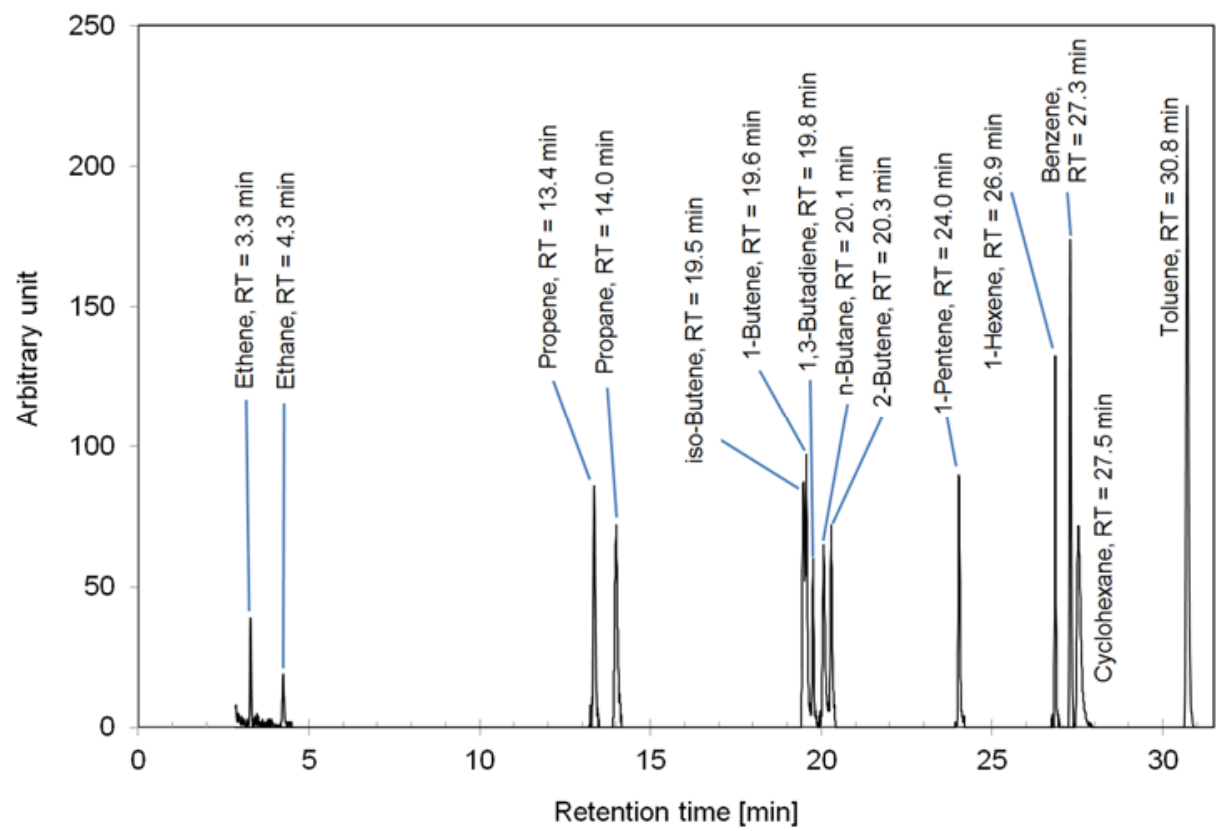

Figure 5 Exemplary gas-chromatogram showing peaks for the undesired side products of autothermal reforming using ATR 14

As a result of these analyses of the reformate of ATR 14 through gas-chromatography and mass spectrometry, Figure 6 displays the molar fractions of unconverted carbon yc as a function of the reformer load at different mass fractions of cold water to the nozzle. For each experiment, the $\mathrm{O}_{2} / \mathrm{C}$ molar ratio was 0.47 , while the $\mathrm{H}_{2} \mathrm{O} / \mathrm{C}$ molar ratio amounted to 1.9 . The temperature of the air to the annular injector was set at $380{ }^{\circ} \mathrm{C}$. Steam from the catalytic burner had a temperature of $230{ }^{\circ} \mathrm{C}$, with Ultimate diesel used as the fuel. When only $30 \%$ of the total mass stream of the water were injected cold, the values for $y_{C}$ were low, in the range of approximately $40 \mathrm{ppm}$. They only slightly depended on the reformer load, which was varied between $50 \%$ and $100 \%$. The minima at $60 \%$ and $70 \%$ load can be explained by comparatively long residence times of the reactants in the catalytic zone, while in parallel the pressures at the nozzle for fuel injection of ATR 14 (11.0 and $16.3 \mathrm{bar}$, respectively) were already high enough to generate a spray of fine fuel droplets to be more easily evaporated in the fuel evaporation chamber. However, when a mass fraction of $40 \%$ cold water was fed into the steam generation chamber of ATR 14 , the values for $y_{C}$ significantly and almost linearly increased from approximately $40 \mathrm{ppm}$ at $50 \%$ of the reformer load to $280 \mathrm{ppm}$ at $100 \%$ reformer load. Here, this clear trend is due to the halved residence time of the reactants at $100 \%$ reformer load in comparison to the $50 \%$ reformer load. The available time span of the 
molecules for interacting with the catalytic active sites was decisively shorter. This trend is also observed at higher mass fractions of cold water to the nozzle of $50 \%$ and $60 \%$. As was mentioned previously, for experimental reasons, during these series of experiments the reformer load could only be increased to $70 \%$ and $60 \%$, respectively. The maximum value for $y_{C}$ was observed at $60 \%$ reformer load and a mass fraction of cold water to the nozzle of $60 \%$, amounting to approximately $570 \mathrm{ppm}$. It is also obvious from this figure that the higher the molar fraction of cold water to the nozzle the higher the values for $y_{C}$. As is shown in Figure 3 , the temperatures at all measuring points inside ATR 14 were clearly lower, when the amount of cold water injected was increased. These lower temperature levels slowed the kinetics of autothermal reforming and thus led to the increased values for the molar fractions of unconverted carbon.

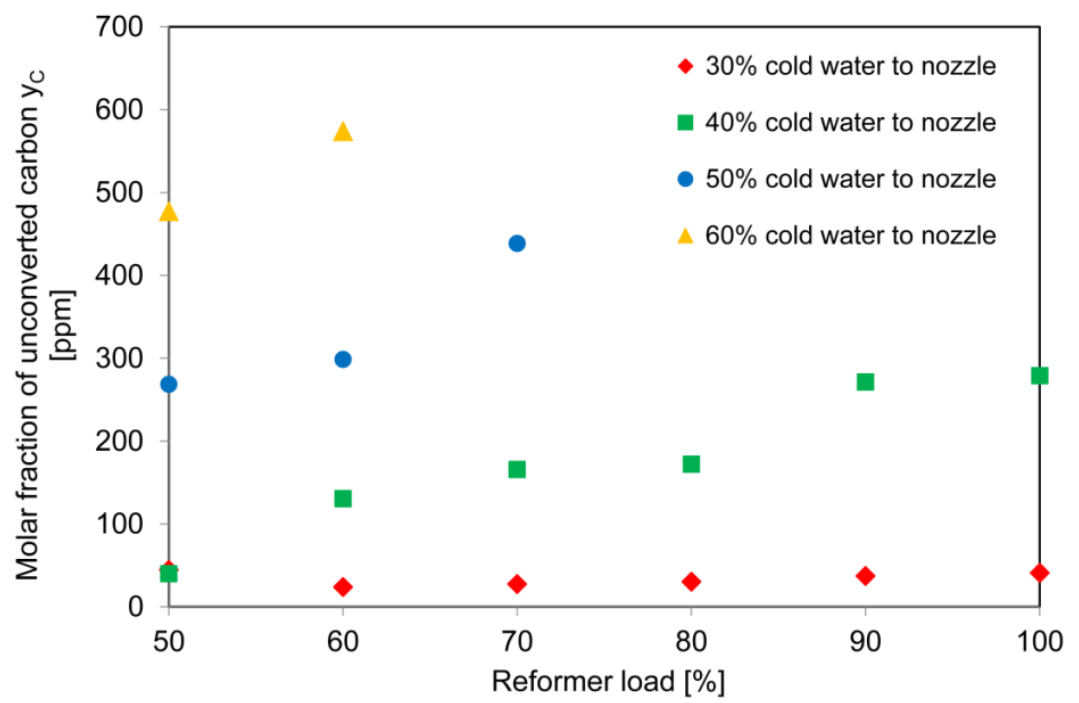

Figure 6 Molar fraction of unconverted carbon $y_{C}$ in the dry reformate as a function of the reformer load at different mass fractions of cold water to the nozzle, $\mathrm{n}\left(\mathrm{O}_{2}\right) / \mathrm{n}(\mathrm{C})=0.47, \mathrm{n}\left(\mathrm{H}_{2} \mathrm{O}\right) / \mathrm{n}(\mathrm{C})=1.9, \mathrm{TAI}=380^{\circ} \mathrm{C}, \quad \mathrm{TCB}=230^{\circ} \mathrm{C}$, fuel: Ultimate diesel

Figure 7 sheds light on how the second pathway for reducing carbon conversion according to equation (5), i.e., the dissolution of unreacted organic carbon in the condensed water at the outlet of ATR 14, developed during the series of experiments reported in this paper. It shows the measured total organic carbon (TOC) as a function of the reformer load at different mass fractions of cold water to the nozzle under the same reaction conditions as are given for Figure 6. As in the case of the molar fractions of unconverted carbon in the dry reformate, the TOC values were also the lowest when only $30 \%$ of the total water mass stream was fed (cold) to the reformer. TOC values varied between $25 \mathrm{ppm}$ and $35 \mathrm{ppm}$, with a minimum at $100 \%$ reformer load. When a mass fraction of $40 \%$ cold water was fed into the steam generation chamber of ATR 14, the TOC values were slightly higher, with values between 40 ppm and $50 \mathrm{ppm}$. They further increased to between $60 \mathrm{ppm}$ and $100 \mathrm{ppm}$ when the mass stream of cold water to the reformer inlet was further enhanced, to $50 \%$ and $60 \%$, 
respectively. On average, there was a slight trend of increasing TOC values with increasing reformer loads. However, this was not as pronounced as in the case of the molar fractions of unconverted carbon in the dry reformate (cf. Figure 6). Nevertheless, also in Figure 7 there is a clear tendency of rising TOC values when the amount of water being coldly injected increased. Again, the resulting lower temperature level at all measuring points inside ATR 14 (cf. Figure 3) was responsible for the experimental finding that undesired side reactions producing unconverted organic compounds dissolved in the condensed water were favored.

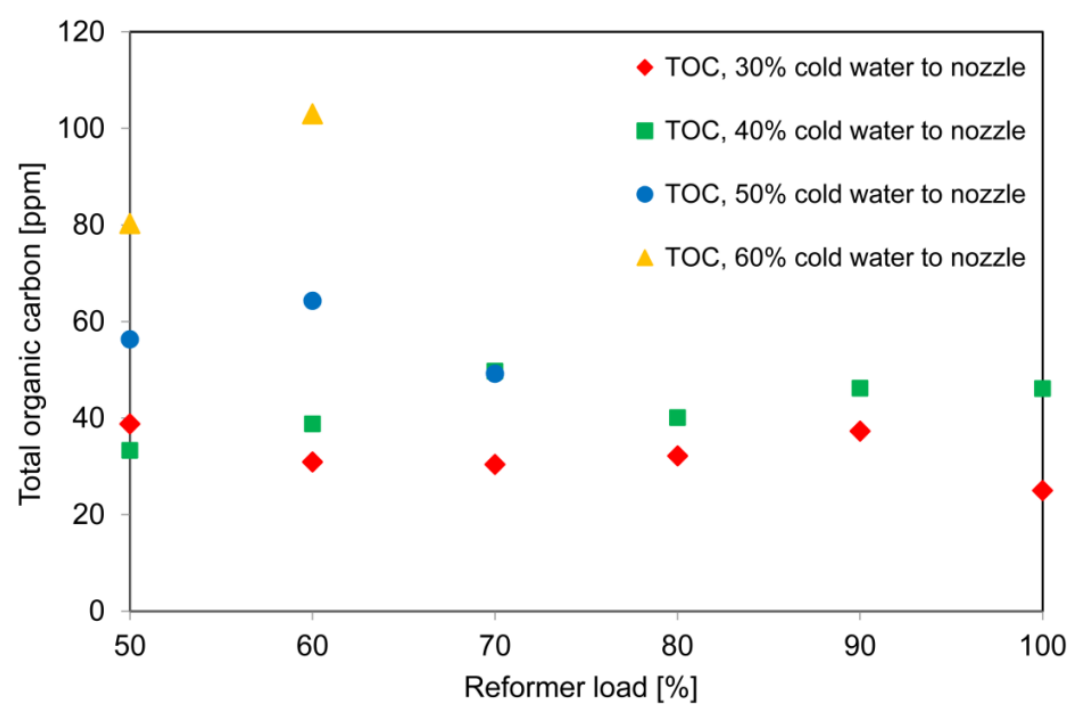

Figure 7 Total organic carbon (TOC) in the condensed water as a function of the reformer load at different mass fractions of cold water to the nozzle, $\mathrm{n}\left(\mathrm{O}_{2}\right) / \mathrm{n}(\mathrm{C})=0.47, \quad \mathrm{n}\left(\mathrm{H}_{2} \mathrm{O}\right) / \mathrm{n}(\mathrm{C})=1.9, \quad \mathrm{TAI}=380^{\circ} \mathrm{C}, \quad \mathrm{TCB}=230^{\circ} \mathrm{C}$, fuel: Ultimate diesel

Based on the experimental data shown in Figure 6 and Figure 7, carbon conversions for each experiment were calculated according to equation (5). These are displayed in Figure 8. The trends of carbon conversion as a function of the reformer load at different mass fractions of cold water to the nozzle at the top of the ATR 14 are, of course, inverse compared to those of the TOC and molar fraction of unconverted carbon $y_{C}$. Carbon conversions were highest when only $30 \%$ of the total mass stream of water was injected (cold) through the nozzle at the top of ATR 14, and showed values in the range of approximately $99.98 \%$. It is noteworthy that even under the most inconvenient reaction conditions noted in this paper, i.e., $60 \%$ reformer load and a mass fraction of cold water to the nozzle of $60 \%$, carbon conversion was still more than $99.7 \%$. This finding supports the conclusion derived previously, that ATR 14 can be properly operated across the entire tested parameter field. 


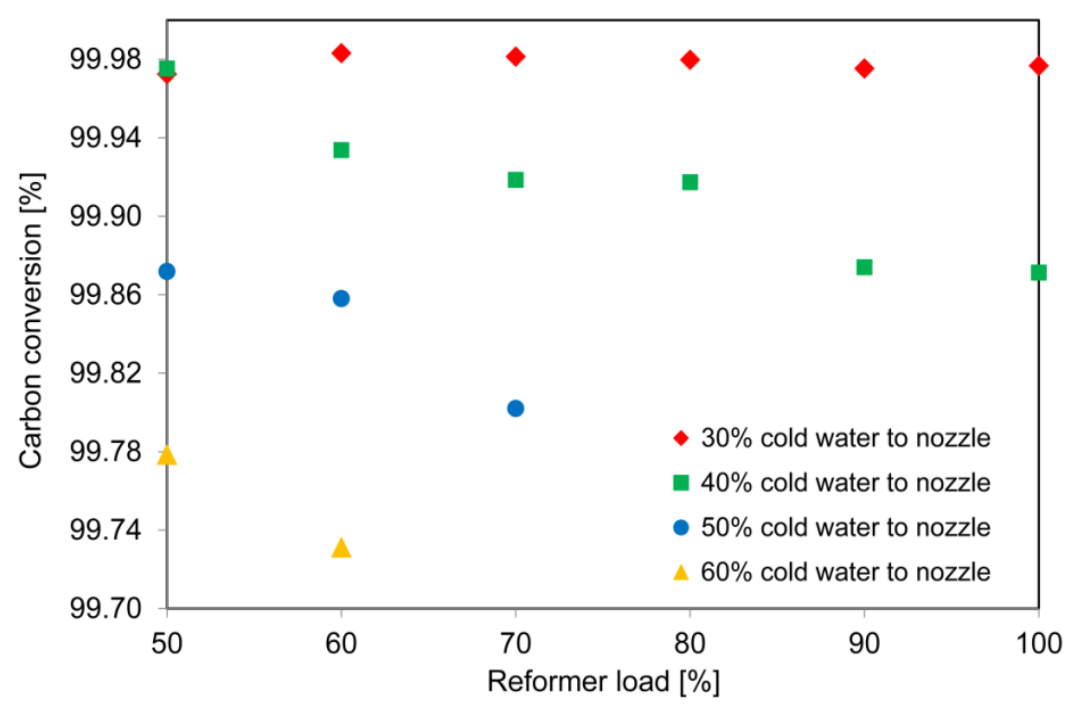

Figure 8 Carbon conversion as a function of the reformer load at different mass fractions of cold water to the nozzle, $\mathrm{n}\left(\mathrm{O}_{2}\right) / \mathrm{n}(\mathrm{C})=0.47, \mathrm{n}\left(\mathrm{H}_{2} \mathrm{O}\right) / \mathrm{n}(\mathrm{C})=1.9$, $\mathrm{TAI}=380{ }^{\circ} \mathrm{C}, \mathrm{TCB}=230{ }^{\circ} \mathrm{C}$, fuel: Ultimate diesel

\section{Conclusions}

The reactor for autothermal reforming in a fuel cell system to be used as, e.g., an auxiliary power unit, is confronted with many requirements from the chemistry, process engineering and design and construction points of view. The most important of these are the complete evaporation of diesel fuel, the homogeneous mixing of all three educts of air, water and diesel fuel, the choice of suitable reaction conditions with a focus on stoichiometrics, internal heat recovery, low pressure drop, fast start-up and suitable placing of the catalytically-coated monolith, guaranteeing plug flow inside of it, a compact and lightweight pressure vessel for the reactor withstanding temperatures up to $600{ }^{\circ} \mathrm{C}$, operation across a broad load range, and finally the transition to commercially-relevant production technologies. As already stated in the section, "Reactor development", ATR 14 can be considered the preliminary conclusion of an autothermal reformer development at Jülich for 15 years, spanning several reactor generations. While the first requirements were worked out and fulfilled in former reactor generations, the focus for the development and experimental evaluation is on the last two points, i.e., operation in a broad load range and the transition to commercially-relevant production technologies. It was demonstrated in this paper that the usage of a pulse valve for injecting diesel fuel in pulse mode widened the load range to values of between $20 \%$ and $100 \%$ with stable trends of reformer temperatures and $\mathrm{H}_{2}$ concentrations. Furthermore, during the experimental evaluation of ATR 14, $\mathrm{H}_{2}$ concentrations in the dry reformate of between 37 vol $\%$ and 39 vol\% and carbon conversions from $99.70 \%$ to $99.98 \%$, depending on the process conditions, were obtained. ATR 14 can be properly run at mass fractions of cold water to the nozzle in the steam generation chamber of $30 \%$ and $40 \%$, ensuring suitable temperature levels in all relevant parts of the reformer for complete diesel evaporation. Many 
parts of ATR 14 were commercially-produced by sheet metal forming. Thus far, for former autothermal reformer generations, milling was applied to produce all single parts. This change in the production technology makes the assembly of ATR 14 much more cost- and timeefficient. This constitutes a major step towards the mass production of ATR 14.

\section{Acknowledgements}

Parts of this work were funded by the Ministry for Climate Protection, Environment, Agriculture, Conservation and Consumer Protection of the German federal state of North Rhine-Westphalia as part of the ADELHEID project. The authors also would like to thank the fuel processing team at Jülich and all project and cooperation partners.

\section{References}

[1] CO2 EMISSIONS FROM CARS: the facts, in: Todts W (Ed.). European Federation for Transport and Environment AISBL, April 2018.

[2] Samsun RC, Wiethege C, Pasel J, Janßen H, Lehnert W, Peters R. HT-PEFC Systems Operating with Diesel and Kerosene for APU Application. Energy Procedia 2012;29:541-51.

[3] Jacob Spendelow DH, Dimitrios Papageorgopoulos. Revised APU Targets, in: Energy Do (Ed.). United States DoE, Washington D.C, 2010, p. 4.

[4] Peters R, Westenberger A. Chapter 4 Large Auxiliary Power Units for Vessels and Airplanes, Innovations in Fuel Cell Technologies. The Royal Society of Chemistry, 2010, pp. 76-148.

[5] Liu D-J, Kaun TD, Liao H-K, Ahmed S. Characterization of kilowatt-scale autothermal reformer for production of hydrogen from heavy hydrocarbons. Int. J. Hydrogen Energy 2004;29:1035-46.

[6] Kaila RK, Krause AOI. Autothermal reforming of simulated gasoline and diesel fuels. Int. J. Hydrogen Energy 2006;31:1934-41.

[7] Kang I, Bae J. Autothermal reforming study of diesel for fuel cell application. J. Power Sources 2006;159:1283-90.

[8] Kang I, Bae J, Bae G. Performance comparison of autothermal reforming for liquid hydrocarbons, gasoline and diesel for fuel cell applications. J. Power Sources 2006; 163:538-46.

[9] Kaila RK, Gutiérrez A, Krause AOI. Autothermal reforming of simulated and commercial diesel: The performance of zirconia-supported RhPt catalyst in the presence of sulfur. Appl. Catal., B 2008;84:324-31.

[10] Harada M, Takanabe K, Kubota J, Domen K, Goto T, Akiyama K, et al. Hydrogen production by autothermal reforming of kerosene over MgAlOx-supported $\mathrm{Rh}$ catalysts. Appl. Catal., A 2009;371:173-8.

[11] Shi L, Bayless DJ, Prudich ME. A CFD model of autothermal reforming. Int. J. Hydrogen Energy 2009;34:7666-75. 
[12] Karatzas X, Creaser D, Grant A, Dawody J, Pettersson LJ. Hydrogen generation from n-tetradecane, low-sulfur and Fischer-Tropsch diesel over Rh supported on alumina doped with ceria/lanthana. Catal. Today 2011;164:190-7.

[13] González AV, Pettersson LJ. Full-scale autothermal reforming for transport applications: The effect of diesel fuel quality. Catal. Today 2013;210:19-25.

[14] Walluk MR, Lin J, Waller MG, Smith DF, Trabold TA. Diesel auto-thermal reforming for solid oxide fuel cell systems: Anode off-gas recycle simulation. Applied Energy 2014;130:94-102.

[15] Xu X, Zhang S, Li P. Autothermal reforming of n-dodecane and desulfurized Jet-A fuel for producing hydrogen-rich syngas. Int. J. Hydrogen Energy 2014;39:19593-602.

[16] Xu X, Zhang S, Wang X, Li P. Fuel adaptability study of a lab-scale $2.5 \mathrm{kWth}$ autothermal reformer. Int. J. Hydrogen Energy 2015;40:6798-808.

[17] Dong J, Xu XH, Xu B, Zhang SY. Parametric analysis of a solid oxide fuel cell auxiliary power unit operating on syngas produced by autothermal reforming of hydrocarbon fuels. Journal of Renewable and Sustainable Energy 2016;8.

[18] García-Díez E, García-Labiano F, de Diego LF, Abad A, Gayán P, Adánez J. Autothermal chemical looping reforming process of different fossil liquid fuels. Int. J. Hydrogen Energy 2017;42:13633-40.

[19] Zhang S, Wang X, Xu X, Li P. Hydrogen production via catalytic autothermal reforming of desulfurized Jet-A fuel. Int. J. Hydrogen Energy 2017;42:1932-41.

[20] Jeong S, Kim D, Lee JH. Modeling and Simulation of Autothermal Reforming Reactor of Diesel over Ni-based Catalyst in Solid Oxide Fuel Cell based Auxiliary Power Unit System, Computer Aided Chemical Engineering, 2018, pp. 613-8.

[21] Lin L, Wu LQ, Sui LR, He SH. Autothermal Reforming of Diesel to Hydrogen and Activity Evaluation. Energy and Fuels 2018;32:7971-7.

[22] Hajjaji N, Pons M-N. Hydrogen production via steam and autothermal reforming of beef tallow: A thermodynamic investigation. Int. J. Hydrogen Energy 2013;38:2199211.

[23] Lin J, Trabold TA, Walluk MR, Smith DF. Bio-fuel reformation for solid oxide fuel cell applications. Part 1: Fuel vaporization and reactant mixing. Int. J. Hydrogen Energy 2013;38:12024-34.

[24] Wang T, Yang Y, Ding M, Liu Q, Ma L. Auto-thermal reforming of biomass raw fuel gas to syngas in a novel reformer: Promotion of hot-electron. Applied Energy 2013;112:448-53.

[25] Lin J, Trabold TA, Walluk MR, Smith DF. Bio-fuel reforming for solid oxide fuel cell applications. Part 2: Biodiesel. Int. J. Hydrogen Energy 2014;39:183-95.

[26] Lin J, Trabold TA, Walluk MR, Smith DF. Bio-fuel reformation for solid oxide fuel cell applications. Part 3: Biodiesel-diesel blends. Int. J. Hydrogen Energy 2014;39:196-208.

[27] Martin S, Kraaij G, Ascher T, Baltzopoulou P, Karagiannakis G, Wails D, et al. Direct steam reforming of diesel and diesel-biodiesel blends for distributed hydrogen generation. Int. J. Hydrogen Energy 2015;40:75-84.

[28] Kirillov VA, Shigarov AB. Biofuels as a promising source of hydrogen for fuel cell power plants. Theoretical Foundations of Chemical Engineering 2016;50:351-65. 
[29] Chen X, Jiang J, Li K, Tian S, Yan F. Energy-efficient biogas reforming process to produce syngas: The enhanced methane conversion by O2. Applied Energy 2017;185, Part 1:687-97.

[30] Erdohelyi A, Cserenyi J, Solymosi F. Activation of $\mathrm{CH}_{4}$ and its reaction with $\mathrm{CO}_{2}$ over supported Rh catalysts. J. Catal. 1993;141:287-99.

[31] Mark MF, Maier WF. $\mathrm{CO}_{2}$-reforming of methane on supported Rh and Ir catalysts. J. Catal. 1996;164:122-30.

[32] Wei J, Iglesia E. Structural requirements and reaction pathways in methane activation and chemical conversion catalyzed by rhodium. J. Catal. 2004;225:116-27.

[33] Ferrandon M, Krause T. Role of the oxide support on the performance of Rh catalysts for the autothermal reforming of gasoline and gasoline surrogates to hydrogen. Appl. Catal., A 2006;311:135-45.

[34] Liu L, Hong L. Nickel phosphide catalyst for autothermal reforming of surrogate gasoline fuel. AIChE Journal 2011;57:3143-52.

[35] Liu L, Hong L. Ni/Ce1-xMx catalyst generated from metallo-organic network for autothermal reforming of diesel surrogate. Appl. Catal., A 2013;459:89-96.

[36] Granlund MZ, Jansson K, Nilsson M, Dawody J, Pettersson LJ. Evaluation of Co, La, and $\mathrm{Mn}$ promoted Rh catalysts for autothermal reforming of commercial diesel. Appl. Catal., B 2014;154-155:386-94.

[37] Granlund MZ, Jansson K, Nilsson M, Dawody J, Pettersson LJ. Evaluation of Co, La, and $\mathrm{Mn}$ promoted $\mathrm{Rh}$ catalysts for autothermal reforming of commercial diesel: Aging and characterization. Appl. Catal., B 2015;172-173:145-53.

[38] Lee S, Bae M, Bae J, Katikaneni SP. Ni-Me/Ce0.9Gd0.1O2-x (Me: Rh, Pt and Ru) catalysts for diesel pre-reforming. Int. J. Hydrogen Energy 2015;40:3207-16.

[39] Xie JY, Sun XJ, Barrett L, Walker BR, Karote DR, Langemeier JM, et al. Autothermal reforming and partial oxidation of $\mathrm{n}$-hexadecane via $\mathrm{Pt} / \mathrm{Ni}$ bimetallic catalysts on ceria-based supports. Int. J. Hydrogen Energy 2015;40:8510-21.

[40] Hbaieb K. Exploring strontium titanate as a reforming catalyst for dodecane. Applied Nanoscience 2016;6:847-54.

[41] Hbaieb K, Rashid KKA, Kooli F. Hydrogen production by autothermal reforming of dodecane over strontium titanate based perovskite catalysts. Int. J. Hydrogen Energy 2017;42:5114-24.

[42] Jeon Y, Lee C, Rhee J, Lee G, Myung JH, Park M, et al. Autothermal reforming of heavy-hydrocarbon fuels by morphology controlled perovskite catalysts using carbon templates. Fuel 2017;187:446-56.

[43] Lee WS, Ju DG, Jung SY, Lee SC, Ha DS, Hwang BW, et al. N-Dodecane Autothermal Reforming Properties of Ni-Al Based Catalysts Prepared by Various Methods. Top Catal 2017;60:727-34.

[44] Shoynkhorova TB, Rogozhnikov VN, Simonov PA, Snytnikov PV, Salanov AN, Kulikov AV, et al. Highly dispersed $\mathrm{Rh} / \mathrm{Ce}_{0.75} \mathrm{Zr}_{0.25} \mathrm{O}_{2}-\delta-\eta-\mathrm{Al}_{2} \mathrm{O}_{3} / \mathrm{FeCrAl}$ wire mesh catalyst for autothermal n-hexadecane reforming. Materials Letters 2018;214:290-2.

[45] Shoynkhorova TB, Simonov PA, Potemkin DI, Snytnikov PV, Belyaev VD, Ishchenko AV, et al. Highly dispersed Rh-, Pt-, $\mathrm{Ru} / \mathrm{Ce} 0.75 \mathrm{Zr}_{0.25} \mathrm{O}_{2}-\Delta$ catalysts prepared 
by sorption-hydrolytic deposition for diesel fuel reforming to syngas. Appl. Catal., B 2018;237:237-44.

[46] Shoynkhorova TB, Rogozhnikov VN, Ruban NV, Shilov VA, Potemkin DI, Simonov $\mathrm{PA}$, et al. Composite $\mathrm{Rh} / \mathrm{Zr}_{0.25} \mathrm{Ce}_{0.75} \mathrm{O}_{2}-\Delta-\eta-\mathrm{Al}_{2} \mathrm{O}_{3} /$ Fecralloy wire mesh honeycomb module for natural gas, LPG and diesel catalytic conversion to syngas. Int. J. Hydrogen Energy 2019;44:9941-8.

[47] Shoynkhorova TB, Snytnikov PV, Simonov PA, Potemkin DI, Rogozhnikov VN, Gerasimov EY, et al. From alumina modified $\mathrm{Rh} / \mathrm{Ce}_{0.75} \mathrm{Zr}_{0.25} \mathrm{O}_{2}-\Delta$ catalyst towards composite $\mathrm{Rh} / \mathrm{Ce}_{0.75} \mathrm{Zr}_{0.25} \mathrm{O}_{2}-\Delta-\eta-\mathrm{Al}_{2} \mathrm{O}_{3} / \mathrm{FeCrAl}$ catalytic system for diesel conversion to syngas. Appl. Catal., B 2019; DOI 10.1016/j.apcatb.2018.12.037:40-8.

[48] Ferrandon M, Mawdsley J, Krause T. Effect of temperature, steam-to-carbon ratio, and alkali metal additives on improving the sulfur tolerance of a $\mathrm{Rh} / \mathrm{La}-\mathrm{Al}_{2} \mathrm{O}_{3}$ catalyst reforming gasoline for fuel cell applications. Appl. Catal., A 2008;342:69-77.

[49] Kang I, Kang Y, Yoon S, Bae G, Bae J. The operating characteristics of solid oxide fuel cells driven by diesel autothermal reformate. Int. J. Hydrogen Energy 2008;33:6298-307.

[50] Yoon S, Kang I, Bae J. Effects of ethylene on carbon formation in diesel autothermal reforming. Int. J. Hydrogen Energy 2008;33:4780-8.

[51] Mayne JM, Tadd AR, Dahlberg KA, Schwank JW. Influence of thiophene on the isooctane reforming activity of Ni-based catalysts. J. Catal. 2010;271:140-52.

[52] Laosiripojana N, Kiatkittipong W, Assabumrungrat S. Partial oxidation of palm fatty acids over Ce-ZrO2: Roles of catalyst surface area, lattice oxygen capacity and mobility. AIChE Journal 2011;57:2861-9.

[53] Mayne JM, Dahlberg KA, Westrich TA, Tadd AR, Schwank JW. Effect of metal particle size on sulfur tolerance of $\mathrm{Ni}$ catalysts during autothermal reforming of isooctane. Appl. Catal., A 2011;400:203-14.

[54] Zheng Q, Janke C, Farrauto R. Steam reforming of sulfur-containing dodecane on a $\mathrm{Rh}$-Pt catalyst: Influence of process parameters on catalyst stability and coke structure. Appl. Catal., B 2014;160-161:525-33.

[55] González AV, Rostrup-Nielsen J, Engvall K, Pettersson LJ. Promoted RhPt bimetallic catalyst supported on $\delta$-A12O3 and $\mathrm{CeO} 2-\mathrm{ZrO} 2$ during full-scale autothermal reforming for automotive applications: Post-mortem characterization. Appl. Catal., A 2015;491:8-16.

[56] Jung SY, Ju DG, Lim EJ, Lee SC, Hwang BW, Kim JC. Study of sulfur-resistant NiAl-based catalysts for autothermal reforming of dodecane. Int. J. Hydrogen Energy 2015;40:13412-22.

[57] Liu L, Hong L. Ceria-supported nickel borate as a sulfur-tolerant catalyst for autothermal reforming of a proxy jet fuel. Catal. Today 2016;263:52-60.

[58] Wierzbicki TA, Lee IC, Gupta AK. Recent advances in catalytic oxidation and reformation of jet fuels. Applied Energy 2016;165:904-18.

[59] Choi WY, Lee JW, Kim MJ, Park CJ, Jeong YH, Choi HY, et al. Durability tests of $\mathrm{Rh} / \mathrm{Al}-\mathrm{Ce}-\mathrm{Zr}$ catalysts coated on NiCrAl metal foam for ATR of dodecane at high temperature. International Journal of Precision Engineering and Manufacturing Green Technology 2017;4:183-9. 
[60] Rogozhnikov VN, Kuzin NA, Snytnikov PV, Potemkin DI, Shoynkhorova TB, Simonov PA, et al. Design, scale-up, and operation of a $\mathrm{Rh} / \mathrm{Ce}_{0.75} \mathrm{Zr}_{0.25} \mathrm{O}_{2}-\delta-\eta$ $\mathrm{Al}_{2} \mathrm{O}_{3} / \mathrm{FeCrAl}$ alloy wire mesh honeycomb catalytic module in diesel autothermal reforming. Chemical Engineering Journal 2019;374:511-9.

[61] da Silva JM, Hermann I, Mengel C, Lucka K, Köhne H. Autothermal reforming of gasoline using a cool flame vaporizer. AIChE Journal 2004;50:1042-50.

[62] Pors Z, Pasel J, Tschauder A, Dahl R, Peters R, Stolten D. Optimised mixture formation for diesel fuel processing. Fuel Cells 2008;8:129-37.

[63] Yoon S, Kang I, Bae J. Suppression of ethylene-induced carbon deposition in diesel autothermal reforming. Int. J. Hydrogen Energy 2009;34:1844-51.

[64] Kim S, Dean AM. The impact of fuel evaporation on the gas-phase kinetics in the mixing region of a diesel autothermal reformer. Int. J. Hydrogen Energy 2015;40:15477-90.

[65] Han G, Lee S, Bae J. Diesel autothermal reforming with hydrogen peroxide for lowoxygen environments. Applied Energy 2015;156:99-106.

[66] Bae J, Lee S, Kim S, Oh J, Choi S, Bae M, et al. Liquid fuel processing for hydrogen production: A review. Int. J. Hydrogen Energy 2016;41:19990-20022.

[67] Han G, Lee K, Ha S, Bae J. Development of a thermally self-sustaining kWe-class diesel reformer using hydrogen peroxide for hydrogen production in low-oxygen environments. J. Power Sources 2016;326:341-8.

[68] Lee K, Han G, Cho S, Bae J. Pressurized diesel fuel processing using hydrogen peroxide for the fuel cell power unit in low-oxygen environments. J. Power Sources 2018;380:37-45.

[69] Pasel J, Wohlrab S, Kreft S, Rotov M, Löhken K, Peters R, et al. Routes for deactivation of different autothermal reforming catalysts. J. Power Sources 2016;325:51-63.

[70] Meißner J, Pasel J, Peters R, Samsun RC, Thimm F, Stolten D. Quantitative analysis of sub-ppm traces of hydrocarbons in the product gas from diesel reforming. Int. J. Hydrogen Energy 2019;44:4020-30.

[71] Pasel J, Samsun RC, Peters R, Stolten D. Fuel Processing of Diesel and Kerosene for Auxiliary Power Unit Applications. Energy Fuels 2013;27:4386-94.

[72] Pasel J, Samsun RC, Tschauder A, Peters R, Stolten D. A novel reactor type for autothermal reforming of diesel fuel and kerosene. Applied Energy 2015;150:176-84.

[73] Pasel J, Samsun RC, Tschauder A, Peters R, Stolten D. Advances in autothermal reformer design. Applied Energy 2017;198:88-98.

[74] Peters R, Pasel J, Samsun RC, Scharf F, Tschauder A, Stolten D. Heat exchanger design for autothermal reforming of diesel. Int. J. Hydrogen Energy 2018;43:1183046.

[75] Samsun RC, Prawitz M, Tschauder A, Pasel J, Pfeifer P, Peters R, et al. An integrated diesel fuel processing system with thermal start-up for fuel cells. Applied Energy 2018;226:145-59.

[76] Lee EJ, Oh SY, Kim HY, James SC, Yoon SS. Measuring air core characteristics of a pressure-swirl atomizer via a transparent acrylic nozzle at various Reynolds numbers. Experimental Thermal and Fluid Science 2010;34:1475-83. 
[77] Peters R, Pasel J, Samsun RC, Scharf F, Tschauder A, Müller M, et al. Spray formation of middle distillates for autothermal reforming. Int. J. Hydrogen Energy 2017;42:16946-60.

[78] Pasel J, Samsun RC, Peters R, Thiele B, Stolten D. Long-term stability at fuel processing of diesel and kerosene. Int. J. Hydrogen Energy 2014;39:18027-36. 